\title{
TU/e EmonONEN

\section{Plasma beam deposited amorphous hydrogenated carbon: improved film quality at higher growth rate}

\section{Citation for published version (APA):}

Gielen, J. W. A. M., Sanden, van de, M. C. M., \& Schram, D. C. (1996). Plasma beam deposited amorphous hydrogenated carbon: improved film quality at higher growth rate. Applied Physics Letters, 69(2), 152-154. https://doi.org/10.1063/1.116904

DOI:

10.1063/1.116904

Document status and date:

Published: 01/01/1996

\section{Document Version:}

Publisher's PDF, also known as Version of Record (includes final page, issue and volume numbers)

\section{Please check the document version of this publication:}

- A submitted manuscript is the version of the article upon submission and before peer-review. There can be important differences between the submitted version and the official published version of record. People interested in the research are advised to contact the author for the final version of the publication, or visit the $\mathrm{DOI}$ to the publisher's website.

- The final author version and the galley proof are versions of the publication after peer review.

- The final published version features the final layout of the paper including the volume, issue and page numbers.

Link to publication

\section{General rights}

Copyright and moral rights for the publications made accessible in the public portal are retained by the authors and/or other copyright owners and it is a condition of accessing publications that users recognise and abide by the legal requirements associated with these rights.

- Users may download and print one copy of any publication from the public portal for the purpose of private study or research.

- You may not further distribute the material or use it for any profit-making activity or commercial gain

- You may freely distribute the URL identifying the publication in the public portal.

If the publication is distributed under the terms of Article 25fa of the Dutch Copyright Act, indicated by the "Taverne" license above, please follow below link for the End User Agreement:

www.tue.nl/taverne

Take down policy

If you believe that this document breaches copyright please contact us at:

openaccess@tue.nl

providing details and we will investigate your claim. 


\title{
Plasma beam deposited amorphous hydrogenated carbon: Improved film quality at higher growth rate
}

\author{
J. W. A. M. Gielen, M. C. M. van de Sanden, ${ }^{a)}$ and D. C. Schram \\ Department of Applied Physics, Eindhoven University of Technology, P.O. Box 513, 5600 MB Eindhoven, \\ The Netherlands
}

(Received 12 March 1996; accepted for publication 13 May 1996)

\begin{abstract}
High quality diamondlike $a-\mathrm{C}: \mathrm{H}$ has been deposited, at low ion bombardment energies, from an expanding thermal argon/acetylene plasma at high growth rate. It is observed that quality improvement, in terms of hardness, is equivalent to maximization of the refractive index. The highest refractive indices are obtained when the admixed acetylene flow and the argon ion flux emanating from the plasma source are comparable in magnitude, which suggests critical loading. This also indicates that the acetylene has to be dissociated only once. Combination with the observed quality behavior at higher deposition rates suggests that there is one preferred hydrocarbon radical for deposition, probably $\mathrm{C}_{2} \mathrm{H}$. (C) 1996 American Institute of Physics.

[S0003-6951(96)02228-0]
\end{abstract}

For several decades it has been known that amorphous hydrogenated carbon $(a-\mathrm{C}: \mathrm{H})$ has important adjustable properties like high hardness, chemical inertness, and infrared transparency. ${ }^{1,2}$ Possible applications are found as protective antireflection coatings in, e.g., bar-code laser scanner devices, and in flat panel displays. Films of $a-\mathrm{C}: \mathrm{H}$ are commonly produced via plasma deposition techniques at growth rates between 0.1 and $1 \mathrm{~nm} / \mathrm{s}^{3}$ For practical technological applications, production costs must be minimized. This implies that the growth rate should be increased, while maintaining good film quality. This quality depends of course, on the application which is foreseen. For example, for wear resistant coatings a hardness above $10 \mathrm{GPa}$ would be desirable. It will be shown that deposition of $a-\mathrm{C}: \mathrm{H}$ films with an expanding thermal plasma ${ }^{4}$ can fulfill this condition. In the past, this technique has been applied successfully for the deposition of diamond, graphite, amorphous hydrogenated silicon, and amorphous (fluoro)hydrogenated carbon. 5,6

The deposition setup consists of a dc plasma arc, a vacuum chamber, and a substrate holder. The $\operatorname{arc}^{4}$ generates a subatmospheric thermal plasma in argon (argon flow: $100 \mathrm{scc} / \mathrm{s}$, electron density: $\approx 10^{22} \mathrm{~m}^{-3}$, electron temperature: $\approx 1 \mathrm{eV}$ ), which expands into the vacuum chamber (pressure: 0.25 mbar) where acetylene is admixed, at about 5 $\mathrm{cm}$ from the arc exit. As the electron temperature in the chamber is low $(\approx 0.2 \mathrm{eV})$ there are no electron induced processes. $^{7}$ The acetylene is only ionized via charge exchange

$$
\mathrm{Ar}^{+}+\mathrm{C}_{2} \mathrm{H}_{2} \rightarrow \mathrm{Ar}+\mathrm{C}_{2} \mathrm{H}_{2}^{+}
$$

with a rate of $\sim 10^{-16} \mathrm{~m}^{3} \mathrm{~s}^{-1} .{ }^{8}$ The formed acetylene ion rapidly recombines dissociatively with an electron

$$
\begin{aligned}
\mathrm{C}_{2} \mathrm{H}_{2}^{+}+e^{-} & \rightarrow \mathrm{C}_{2} \mathrm{H}+\mathrm{H} \\
& \rightarrow \mathrm{CH}+\mathrm{CH} \\
& \rightarrow \mathrm{C}_{2}+\mathrm{H}_{2},
\end{aligned}
$$

with a rate of about $3 \times 10^{-13} \mathrm{~m}^{3} \mathrm{~s}^{-1} \cdot{ }^{9}$ As will be argued later, the $\mathrm{C}_{2} \mathrm{H}+\mathrm{H}$ channel will probably be predominant. The active plasma mixture is then transported at a velocity of about $1000 \mathrm{~m} / \mathrm{s}$ towards the water-cooled, grounded, nonbiased, substrate holder, which is positioned at $65 \mathrm{~cm}$ from the arc exit. No active temperature control is carried out, but from infrared interferometry, using a double polished silicon substrate, it is determined that the substrate temperature is always less than $100{ }^{\circ} \mathrm{C} .{ }^{10}$

The films are grown on glass and crystalline silicon substrates $\left(2.5 \times 2.5 \mathrm{~cm}^{2}\right)$. The plasma parameters varied during deposition are the electrical current through the arc (20-88 A), which determines the ionization degree of the argon gas, and the admixed acetylene flow $(2-20 \mathrm{scc} / \mathrm{s})$, which is a measure for the hydrocarbon particle flux.

Characterization of the film properties is performed via various ex situ diagnostics. ${ }^{11}$ It is found that all properties show clear relations with the refractive index, independent of which plasma parameter (arc current or acetylene flow) is varied. The refractive index is obtained from infrared absorption spectroscopy and is known to be an indicator for film quality. ${ }^{12}$ The microhardness, determined via nanoindentation, ${ }^{13}$ is found to increase with increasing refractive index from about 4 to $13 \mathrm{GPa}$ (see Fig. 1), which implies a shift from soft polymerlike material to hard diamondlike. All

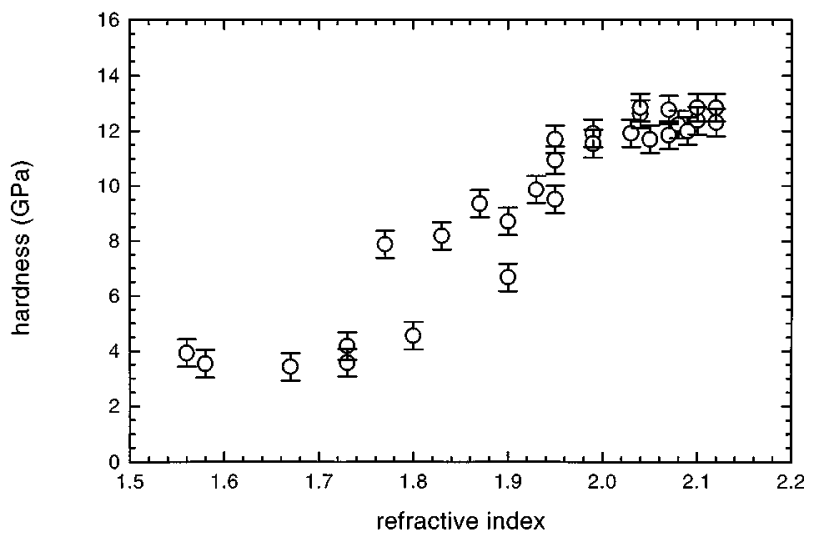

FIG. 1. The microhardness of the films vs the infrared refractive index. 
TABLE I. Properties of plasma beam deposited diamondlike $a-\mathrm{C}: \mathrm{H}$ films and other PECVD techniques (Refs. 17-19).

\begin{tabular}{ccc}
\hline \hline Film property & Plasma beam deposition & PECVD \\
\hline Hardness & $13 \mathrm{GPa}$ & $10-20 \mathrm{GPa}$ \\
Optical band gap & $1.0-1.3 \mathrm{eV}$ & $1.1 \mathrm{eV}$ \\
Mass density & $1.7 \mathrm{~g} / \mathrm{cm}^{3}$ & $1.4-1.9 \mathrm{~g} / \mathrm{cm}^{3}$ \\
$s p^{3}: s p^{2}: s p^{1}$ & $75: 22: 3$ & $68: 30: 2$ \\
$\mathrm{CH}: \mathrm{CH}_{2}: \mathrm{CH}_{3}$ & $54: 44: 2$ & $60: 40: 0$ \\
Hydrogen content & $23-34$ at. $\%$ & 27 at. $\%$ \\
Refractive index (visible) & 2.05 & 2.0 \\
Refractive index (infrared) & $1.95-2.09$ & $1.67-2.69$ \\
\hline \hline
\end{tabular}

films are found to adhere well to the substrate. The hydrogen density (bonded and nonbonded) and the optical band gap decrease at increasing refractive index. The latter is in agreement with the observed increment in the $s p^{2} / s p^{3}$ ratio, which indicates an enhanced cluster formation. ${ }^{14,15}$ From infrared absorption spectroscopy indeed an increment in aromatic $s p^{2} \mathrm{CH}$ bonds is found. Furthermore, it is observed that the widths of the deconvoluted infrared $\mathrm{C}-\mathrm{H}$ absorption peaks increase with increasing refractive index, which also indicates harder material. ${ }^{16}$

In Table I, the determined properties for diamondlike $a-\mathrm{C}: \mathrm{H}$ films (high refractive index), using the different film diagnostics, are summarized. Also, the typical diamondlike properties of films deposited with other PECVD techniques are given. ${ }^{17-19}$ It is obvious that plasma beam deposited diamondlike $a-\mathrm{C}: \mathrm{H}$ is of similar quality. However, note that no external substrate bias is applied during deposition. In general a bias of $\sim 100 \mathrm{~V}$ per deposited $\mathrm{C}$ atom is needed to obtain diamondlike properties. ${ }^{20-24}$

The highest $a-\mathrm{C}: \mathrm{H}$ hardness is observed at the highest refractive index. Thus, improving film quality is equivalent to maximizing the refractive index. In Fig. 2 the latter property is given as a function of the admixed acetylene gas flow at various arc currents. For each applied arc current a similar trend with increasing acetylene flow is found: the refractive index first increases until a maximum is reached, then it decreases.

Figure 2 suggests the following mechanism for the deposition of plasma beam deposited $a-\mathrm{C}: \mathrm{H}$. At a fixed arc current, a constant flux of argon ions emanates from the plasma source. From Langmuir probe measurements ${ }^{25}$ this flux is

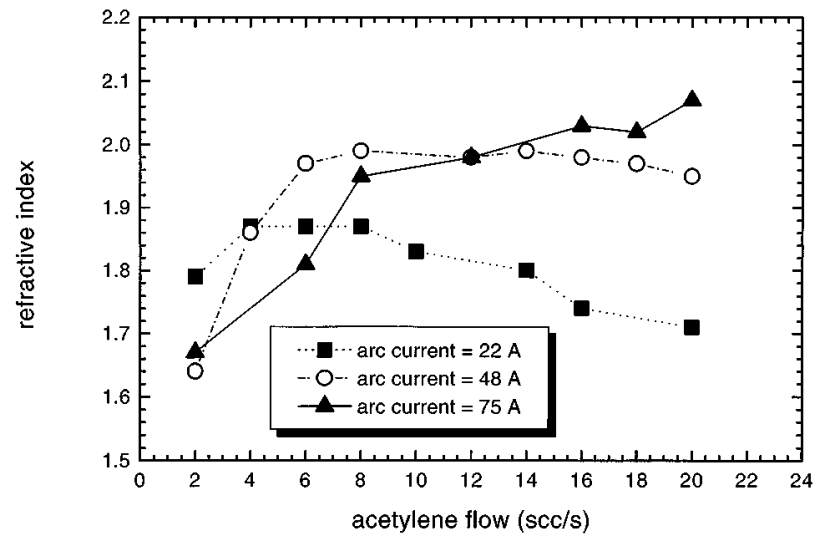

FIG. 2. The infrared refractive index vs the admixed acetylene flow, for three arc current settings.

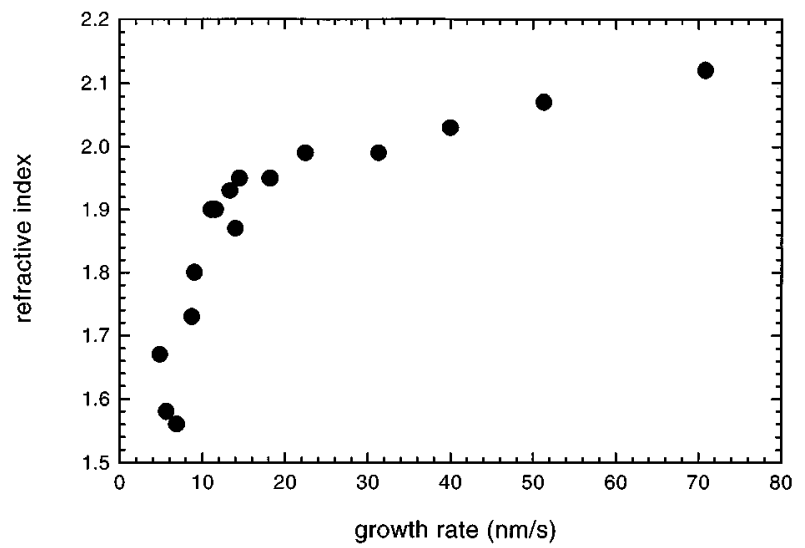

FIG. 3. The infrared refractive index vs the growth rate. Both the arc current (20-88 A) and the admixed acetylene flow (2-20 scc/s) are varied.

found to vary from $5 \%$ to $25 \%$ of the argon neutral flux at increasing arc current (22-75 A). Ionization of the acetylene molecules occurs via reaction (1), directly followed by the dissociative recombination via (2). The maximum refractive index is observed at an admixed acetylene flow which is comparable to the argon ion flux emanating from the source. This suggests a critical loading of acetylene with respect to the argon ion flux in the plasma. This also indicates that the acetylene has to be dissociated only once and that the radicals thus formed are responsible for a good film quality. Both underloading and overloading of the plasma with acetylene, in comparison with the argon ion flux, is proven to be unfavorable for film quality. Underloading results in an enhanced ionization and dissociation of the formed hydrocarbon radicals and overloading probably results in clustering or direct deposition of acetylene. ${ }^{26}$ The mean free path for acetylene to react with an argon ion is about $20 \mathrm{~cm}$. Probe measurements at $25 \mathrm{~cm}$ from the acetylene injection point show that in the case of critical loading more than $90 \%$ of the argon ion density is lost, ${ }^{25}$ excluding further ionization and dissociation of the formed radicals. This shows that the deposition process is dominated by radicals.

The one step ionization and dissociative recombination of acetylene [Eqs. (1) and (2)] can result, as already mentioned, in various reaction products. The exact branching ratio of each product reaction path is presently unknown. However, based on energetic, statistical phase space and stereometric arguments, ${ }^{27}$ there are strong indications that $\mathrm{C}_{2} \mathrm{H}$ is the most important radical.

The existence of one preferred deposition radical might also be concluded from the refractive index behavior with respect to growth rate variation. The latter is a measure for the hydrocarbon particle flux towards the growing film surface which contributes to growth. The refractive index is found to increase with increasing growth rate (see Fig. 3). At higher rates the quality still improves but less dramatic. This could indicate that the plasma composition is well established, with respect to one certain growing particle, e.g., $\mathrm{C}_{2} \mathrm{H}$ (ethinyl). The growth rate increment then is a result of an enhanced particle flux towards the substrate, which influences the film quality only marginally. The result in Fig. 3 is very important, as presently, better $a-\mathrm{C}: \mathrm{H}$ films are deposited 
at higher deposition rates (currently the maximum hardness is $13 \mathrm{GPa}$ at a rate of $75 \mathrm{~nm} / \mathrm{s}$ ).

In conclusion, the use of an expanding thermal plasma, without substrate bias and thus low ion bombardment energies, allows the deposition of diamondlike $a-\mathrm{C}: \mathrm{H}$ with similar properties as other PECVD techniques, but at a deposition rate which is at least two orders of magnitude higher. It is observed that quality improvement is equivalent with maximizing the refractive index. At a specific source setting, this maximum is reached when the admixed acetylene flow and the argon ion flux from the plasma source are comparable (critical loading). This indicates a one step dissociation mechanism of acetylene. Combination with the observed quality improvement behavior at higher growth rates, suggests that there might be one dominant hydrocarbon radical (probably $\mathrm{C}_{2} \mathrm{H}$ ) which is responsible for good diamondlike $a-\mathrm{C}: \mathrm{H}$.

The authors greatly appreciate the skillful technical assistance of M. J. F. van de Sande, A. B. M. Hüsken, and H. M. M. de Jong. The foundation of Fundamental Research on Matter (FOM) and the Royal Netherlands Academy For Arts and Science (KNAW) are acknowledged for their financial support. E. H. A. Dekempeneer and J. Meneve - VITO Institute, Mol (Belgium) - and L. J. van IJzendoorn (Eindhoven University of Technology) are thanked for performing the nanoindentation and ERDA/RBS measurements. Patrick Kleuskens and Mark van der Zande are acknowledged for participating in the experiments.

${ }^{1}$ J. C. Angus and Y. Wang, in Diamond and Diamond-like Films and Coatings, NATO ASI Series B, Vol. 266, edited by R. E. Clausing, L. L. Horton, J. C. Angus, and P. Koidl (Plenum, New York, 1991), p. 173.

${ }^{2}$ J. C. Angus, P. Koidl, and S. Domitz, in Plasma Deposited Thin Films, edited by J. Mort and F. Jansen (CRC, Boca Raton, FL, 1986), p. 89.

${ }^{3}$ Y. Catherine, in Diamond and Diamond-like Films and Coatings, NATO ASI Series B, Vol. 266, edited by R. E. Clausing, L. L. Horton, J. C. Angus, and P. Koidl (Plenum, New York, 1991), p. 193.

${ }^{4}$ J. W. A. M. Gielen, M. C. M. van de Sanden, P. R. M. Kleuskens, and
D. C. Schram, Plasma Sources Sci. Technol. 5 (1996) (in press).

${ }^{5}$ J. J. Beulens, A. J. M. Buuron, M. J. de Graaf, G. J. Meeusen, M. C. M. van de Sanden, A. T. M. Wilbers, and D. C. Schram, High Temp. Chem. Proc. 1, 105 (1992).

${ }^{6}$ J. W. A. M. Gielen, M. C. M. van de Sanden, and D. C. Schram, Thin Solid Films 271, 56 (1995).

${ }^{7}$ M. C. M. van de Sanden, J. M. de Regt, and D. C. Schram, Plasma Sources Sci. Technol. 3, 501 (1994).

${ }^{8}$ W. B. Maier, J. Chem. Phys. 42, 1790 (1965).

${ }^{9}$ P. M. Mul and J. Wm. McGowan, Astrophys. 237, 749 (1980).

${ }^{10}$ E. S. Aydil, J. A. Gregus, and R. A. Gottscho, Rev. Sci. Instrum. 64, 3572 (1993).

${ }^{11}$ J. W. A. M. Gielen, M. C. M. van de Sanden, P. R. M. Kleuskens, L. J. van IJzendoorn, D. C. Schram, E. H. A. Dekempeneer, and J. Meneve (unpublished).

${ }^{12}$ K. Donnelly, D. P. Dowling, E. Davitt, T. P. O'Brien, and T. C. Kelly, Proc. Adv. Mater. Proc. Technol. 769 (1993).

${ }^{13}$ J. L. Loubet, J. M. Georges, and G. Meile, ASTM Spec. Techn. 889, 72 (1986).

${ }^{14}$ J. Robertson and E. P. O’Reilly, Phys. Rev. B 35, 2946 (1987).

${ }^{15}$ J. Robertson, Diam. Relat. Mater. 4, 297 (1995).

${ }^{16}$ B. Dischler, E-MRS Meeting 17, 189 (1987).

${ }^{17}$ P. Koidl, C. Wild, R. Locher, and R. E. Sah, in Diamond and Diamondlike Films and Coatings, NATO ASI Series B, Vol. 266, edited by R. E. Clausing, L. L. Horton, J. C. Angus and P. Koidl (Plenum, New York, 1991), p. 243.

${ }^{18} \mathrm{~J}$. Robertson, in Diamond and Diamond-like Films and Coatings, NATO ASI Series B, Vol. 266, edited by R. E. Clausing, L. L. Horton, J. C. Angus, and P. Koidl (Plenum, New York, 1991), p. 331.

${ }^{19}$ O. Stenzel, R. Petrich, and M. Vogel, Opt. Mater. 2, 125 (1993).

${ }^{20}$ N. Fourches and G. Turban, Thin Solid Films 240, 28 (1994).

${ }^{21}$ P. Reinke, W. Jacob, and W. Möller, J. Appl. Phys. 74, 1354 (1993).

${ }^{22}$ A. von Keudell, W. Jacob, and W. Fukarek, Appl. Phys. Lett. 66, 1322 (1995).

${ }^{23}$ S. Xu, M. Mundhausen, J. Ristein, B. Yan, and L. Ley, J. Non-Cryst. Solids 164-166, 1127 (1993).

${ }^{24}$ L. Martinu, A. Raveh, A. Dominique, L. Bertrand, J. E. KlembergSapieha, S. C. Gujrathi, and M. R. Wertheimer, Thin Solid Films 208, 42 (1992).

${ }^{25}$ J. W. A. M. Gielen, M. C. M. van de Sanden, W. M. M. Kessels, and D. C. Schram, Mater. Res. Soc. Symp. Proc. (to be published).

${ }^{26}$ S. A. Miller, Acetylene, it's Properties, Manufacture and Uses (Ernest Benn, London, 1965).

${ }^{27}$ E. Herbst, Astrophys. J. 222, 508 (1978). 